En sidste positiv ting skal fremhæves. Indskudt $\mathrm{i}$ teksten præsenteres man løbende for nogle cases, som belyser de problemstillinger, der behandles i hovedteksten. De velvalgte cases spænder vidt; fra Lomborgsagen til dobbeltblinde placebo-eksperimenter, fra dyreforsøg til Sokal-affæren. Det fungerer godt og giver de teoretiske overvejelser substans og relevans. Det er netop bogens overordnede styrke, at den manøvrerer så sikkert i rummet mellem teoretisk abstraktion og praktisk anvendelighed, og derfor kan bogen også anbefales til enhver med interesse for videnskabsetik og alle, der udfolder videnskab i praksis.

Casper Andersen

\section{Pippi og Sokrates i filosofisk ojenhojde?}

Jorgen Gaarde og Oystein Sjaastad: Pippi og Sokrates - et filosofisk drikkegilde $i$ Villa Villakulla,. Oversat af Joachim Wrang, Forlaget Klim, 2004, 243 s., $269 \mathrm{kr}$.

De to norske forfattere Jørgen Gaarde og Øystein Sjøstad lancerer i bogen Pippi og Sokrates - et filosofisk drikkegilde $i$ Villa Villakulla Pippi Langstrømpe som en slags 'barndommens spørgeJørgen' i stil med filosoffen Sokrates. Gaare og Sjaastads bog er bygget op af tolv kapitler, der behandler filosofiske temaer i Pippi-bøgerne med virkningsfulde perspektiveringer til Astrid Lindgrens (1907-2002) øvrige forfatterskab og ikke mindst til den filosofiske tradition.

Allerede hvad formen angår, forsøger de to forfattere at tage kampen op med Platon (!), idet bogens kapitler placeres inden for en såkaldt rammedialog. Denne rammedialog foregår mellem de to tænkte forfattere, Teodor og Agaton, der både optræder som Pippis sørøver-kompagnoner og som Sokrates' venner fra Athen, og som igen - selvfølgelig - er de to, 'virkelige' forfatteres talerør. Desværre lykkes forsøget kun delvist. Dels fordi formålet er at skabe en dialog mellem Pippi og Sokrates på tværs af tid og rum (hvilket Pippi tydeligvis ikke er gearet til!), og dels et praktisk bindeled mellem de enkelte kapitler. Men samtidig skal det siges, at bogen er velskrevet, letlæst og tillige underholdende.

Som andre anmeldere har bemærket det, er flere af kapitlerne 'rene perler'. Dette gælder f.eks. efter min opfattelse kapitlet om den pessimistiske eller tragikomiske dimension hos Pippi og Astrid Lindgren. Som da de to gamle koner mødes på kirkegården, og den ene siger til den anden: 'Her skal vi alle mødes, hvis vi lever så længe og beholder vores gode helbred'. Eller med filurikus-pillerne, der skal fastholde Pippi, Annika og Tommy evigt $\mathrm{i}$ barndommens rige. Et andet eksempel er kapitlet om Pippis forhold til rod og skidt, hvor Pippi så at sige sætter tingene på plads ved at vende op og ned på alting. Et tredje det ubetalige afsnit om Pippis 'via 
negativa' $i$ jagten på betydningen af ordet 'spunk', som hun selv har fundet på: Selvom hun ganske vist ikke er helt på det rene med, hvad ordet spunk egentlig betyder: 'Det eneste, jeg ved, er at det ikke betyder støvsuger' (s.147).

Forfatternes egen påstand er i udgangspunktet den, at man blandt børn finder nogle af de mere filosofiske hoveder, fordi de endnu ikke er blevet låst i deres tænkemåde af de herskende normer (bredt forstået), idet Astrid Lindgrens Pippi-bøger netop skal ses i lyset heraf. I den forstand er bogen ikke mindst en demonstration af og en kærlighedserklæring til Astrid Lindgrens 'fænomenologi', herunder ikke mindst hendes indsigt i ligheder og forskelle mellem børns og voksnes forestillings- og tankeverden, og herunder ikke mindst den rolle, som den filosofiske inspiration - bevidst såvel som ubevidst - spiller for hende $i$ hendes litterære univers.

Ligesom Sokrates går Pippi rundt som et fremmedlegeme $\mathrm{i}$ byen, er en 'idiotes', og begge opfører de sig også mærkeligt, ser mærkelige ud og stiller mærkelige og drilske spørgsmål til den gældende 'doxa'. Selv hævdede Lindgren da også oprindelig, at Pippi var at betragte som et lille, 'Nietzscheansk' overmenneske, der bruger sin magt i det godes tjeneste. Men også (lighederne med) andre af filosofiens store inddrages, såsom Wittgenstein, Kierkegaard, Sartre og Simone de Beauvoir og Hegel. Og det er afgjort heri, at bogen er stærkest, men også svagest, for så snart en analogi er påpeget gåes der hurtigt videre til den næste analogi $\mathrm{i}$ et hæsblæsende, men samtidig hele tiden humørfyldt tempo, der desværre undertiden tager form af en opremsning af positioner.

Man kunne således godt have ønsket sig lidt mere dybdegående fortolkninger af, hvor det er, at vandene skiller, særligt $\mathrm{i}$ forhold til det uafviselige slægtskab mellem Pippi og Sokrates (og Nietzsche): Sokrates indsigtsfulde uvidenhed, som man evt. kan nå frem til, er jo ikke, hvilket Johannes Sløk i sin tid gjorde et stort nummer ud af i Herre giv mig mere vantro! (1988), uden videre den samme, som den uvidenhed i hvilken man begynder, og tillige forbliver $i$, dvs. hvis man, som Pippi, tendentielt fornægter den traditionelle (ud)dannelse til fordel for hjertets dannelse alene. Så hvorfor er det lige, at Sokrates er at regne for historiens måske væsentligste filosof, ved netop at spørge reflekteret til (fraværet af) dette gode, mens Pippi - bevares - med sit uimodståelige artisteri, sin anarkisme og sine karnevaleske indslag er en lidt mindre af slagsen? Dette spørgsmål belyses ikke helt tilfredsstillende i bogen. Også fordi forfatterne ikke kan blive helt enige med sig selv om, hvad det egentlig er for en Sokrates-figur, som de sammenligner Pippi med, dvs. om det er Platons, Aristofanes (Kierkegaards i disputatsen), Xenofons eller en helt fjerde. 
Er forholdet til Sokrates og den undertiden manglende analytiske dybde svage punkter i bogen, så er forfatternes demonstration af Pippi, Emils og Karlssons 'overmenneskelige' Zarathustra-attituder og impulsive magtvilje a la Nietzsche til gengæld veldokumenteret, hvorfor analysen af såvel Pippi som Nietzsche, samt forbindelsen imellem dem, kommer bedre af sted. Forfatterne lægger sig her i forlængelse af Brandes' udlægninger af Nietzsche som en 'aristokratisk radikalist', og argumenterer altså for, at Pippi bør ses som et lille 'overmenneske. Lad så være, at Pippi på den måde, og igen som følge af analogitvangen, både fremtræder som et lille, Nietzscheansk, uregerligt og impulsivt handlende 'Übermensch' på den ene side, og som Sokratisk, reflekteret og ironisk maieutiker på den anden.

I forlængelse af denne modsigelse kan man være fristet til at hævde, at mange børn simpelt hen er vilde med Pippi, dels fordi hun netop er ganske 'barnlig' i sin væremåde (f.eks. sårbar som følge af savnet af forældrene), og dels fordi hun samtidig er aldeles opsætsig i sit adfærdsmønster. Dette mere end de elsker hende for den selvstændige og kritiske tænkning på højeste niveau, som hun ifølge de to norske forfattere gerne skulle give anledning til med sin anfægtelse af ethvert tabu osv.. Hverken det 'barnlige' islæt eller opsætsigheden gør således i sig selv Pippi til hverken Sokratisk filosof eller Nietzscheansk overmenneske! Mere positivt formuleret kan man sige, forfatterne har forstået den dimension hos Astrid Lindgren, som vi andre vitterlig også må elske hende for; nemlig den, at hendes bøger rummer og kan læses på flere niveauer, dvs. både af børn og voksne, både 'umiddelbart', bogstaveligt, og 'reflekterende', allegorisk. Og det er skam slet ikk' så ring' endda! Så kan man godt se gennem fingre med, at man, hvad dybdegående og sammenhrngende filosofiske analyser angår, ikke kan klare sig med det filosofiske drikkegilde i Villa Villakulla alene, men selv må gå videre med udforskningen af den filosofiske rodekasse, hvor der bl.a. gemmer sig 'skunker'.

\section{Jens Viggo Nielsen}

\section{Islam med danske ojne}

Jorgen Bak Simonsen: Islam med danske ojne - danskernes syn på islam gennem 1000 år, Akademisk Forlag 2004, 215 s., $249 \mathrm{kr}$.

Jeg kom under læsningen af Jørgen Bæk Simonsens (JBS) nye bog Islam med danske ojne (IDØ) til at huske på en udtalelse af Mawlana Hazar Imam (en ledende figur inden for den shiamuslimske retning ismailitterne) om, at der ikke findes et clash of civilizations imellem Islam og Vesten; men at der er derimod findes et clash of ignorance fra begge sider. JBS forsøger i ID $\varnothing$, ligesom i sin tidligere bog Det retfardige samfund, netop at medvirke 